\title{
Impacts of seasonal ambient temperature and humidity on meat quality characteristics of sheep and beef longissimus thoracis muscles
}

\author{
Issa Al-Amria*, Isam T. kadim ${ }^{a *}$, Dawood S. Al-Ajmi , Abdulaziz Alkindia, Alaa A. Sawadc, Ahmed Hamaed ${ }^{a}$, \\ Amira Nasser ${ }^{d}$ \\ ${ }^{a}$ Department of Biological Sciences and Chemistry, College of Arts and Sciences, University of Nizwa, PO Box 33, PC 616, Birkat Al-Mouz, \\ Nizwa, Sultanate of Oman, ${ }^{b}$ Department of Integrative Agriculture, College of Food and Agriculture, United Arab Emirates University, PO \\ Box 15551, Al-Ain, UAE, 'C College of Veterinary Medicine, University of Basrah, Basrah, Iraq, 'Department of Animal production, College of \\ Agriculture, University of Basrah, Basrah, Iraq
}

\section{A B S TR A C T}

The effects of seasonal temperature and humidity on meat quality characteristics of sheep (12 months of age) and beef cattle (24 months of age) were investigated. Samples of longissimus thoracis $(500 \mathrm{~g})$ muscle were randomly collected from 96 sheep and 48 beef cattle between November 2018 and October 2019. All the meat samples were kept in the chiller at $4-5^{\circ} \mathrm{C}$ for $48 \mathrm{~h}$. The samples were collected over a 12-month period and this period was divided into two seasons based on ambient temperature and relative humidity in Basrah region. Theses seasons were named: Cool Season (November to March with average temperature of $23.0 \pm 1.54^{\circ} \mathrm{C}$ and $59.0 \pm 1.75 \%$ relative humidity) and Hot Season (April to October with average temperature of $40.5 \pm 1.77^{\circ} \mathrm{C}$ and $53.5 \pm 5.98$ relative humidity). The ultimate $\mathrm{pH}(\mathrm{pHu})$, expressed juice, cooking losses, shear force, sarcomere length, myofibrillar fragmentation index and colour lightness $\left(L^{*}\right)$, redness $\left(a^{*}\right)$, and yellowness $\left(b^{*}\right)$ parameters were determined. The effect of the season on meat quality characteristics of the Longissimus thoracis muscle from both species was found to be significant $(\mathrm{P}<0.05)$. The hot season muscle samples had significantly $(P<0.05)$ higher $\mathrm{pHu}$ values, longer sarcomere length, higher myofibrillar fragmentation index with significantly $(P<0.05)$ lower shear force values than the muscle samples collected during the cool season. Sheep and beef longissimus thoracis muscles from the hot season group had significantly $(\mathrm{P}<0.05)$ darker meat than that those of the cold season group, based on $L^{*}, a^{*}$ and $b^{*}$ colour measurements. The present findings indicated that hot temperature $\left(>40^{\circ} \mathrm{C}\right)$ leads to heat stress in sheep and cattle, which increased the muscle pHu and influenced other related meat properties. These findings will assist meat producers to improve meat quality parameters by slaughtering livestock at early hours of the day. Hot temperature has also an impact on animal welfare.

Keywords: Cattle; Expressed juice; Meat quality; Longissimus thoracis; Shear force; Sheep

\section{INTRODUCTION}

The climate change with high ambient temperature is one of the most important physiological stressors to constraint animal productivity due to the thermoregulation mechanisms of animal's represents great expenses in energy for heating loss. According to Hashem et al. (2013), animal may fail to adapt to extreme heat stress, which will lead to great impact into animal's productivity and a huge economic loss for the animal industry. Ambient temperature and humidity in Basrah region during hot season may alter animal's metabolic system and reduce production performance and carcass quality. As ambient temperature in Iraq have been rising since the 1950s, particularly during summer season, while the duration, intensity and frequency of extreme heat events have also been increasing (Iraqi Meteorological Organization and Seismology). The heat stress issue in Basrah region is expected to get more pronounced as a result of climate change due to greenhouse effect. It has been shown that heat stress not only leads to physiological and metabolic perturbations in animals but may also affect meat quality characteristics plausibly by fluctuating the rate and extent of postmortem muscle glycolysis and subsequent $\mathrm{pH}$ (Zhang et al., 2020). The fluctuations in ambient temperature have a great effect on the animal's ability to maintain its own body temperature which will

\footnotetext{
${ }^{*}$ Corresponding author:

Issa Al-Amri, Department of Biological Sciences and Chemistry, College of Arts and Sciences, University of Nizwa, PO Box 33, PC 616, Birkat Al-Mouz, Nizwa, Sultanate of Oman. E-mail: isam@unizwa.edu.om. (I.T. Kadim)
}

Received: 02 February 2021; $\quad$ Accepted: 18 April 2021 
deteriorate the quality of the meat (Lehotayová et al., 2012; Gonzalez-Rivasa et al., 2020). According to Gregory (2010), high ambient temperature could affect animal meat quality characteristics by directly affecting the organ and the muscle metabolism and indirectly by affecting the meat quality due to the changes in the management practice in to adapt to the variation caused by climate change. The pre-slaughter atmospheric conditions must be considered as they may cause additional stress on animals. Even though it was proved that physiological stress affects meat quality (Kadim et al., 2004, 2008; Chulayo and Muchenje, 2013), the direct effect of seasonal temperature and humidity in Basrah region on meat quality parameters was not considered. Cattle and sheep meat products are considered the most favorable meats by the region's consumers. In general, during hot season, some stressful behaviors of impaired physiological functions and increased incidence of morbidity were detected in some animals (Hahn and Mader, 1997; Kadim et al., 2008). The responses of various livestock to weather may be very pronounced and should be taken into consideration under hot condition in order to evaluate its effects on meat quality characteristics. The main endocrine responses to stress involve hormones that suppress energy storage and promote energy utilization from stores (Nelson and Drazen, 2000, Kadim et al., 2006, 2008).

Variation in weather temperature and humidity may have some effects on muscle glycogen storage at time of slaughter and then smay influence the meat $\mathrm{pH}$, which could affect the quality characteristics of sheep and beef (Kadim et al., 2008; Zhang et al., 2020). It has been shown that increases in $\mathrm{pHu}$ of the longissimus thoracic from 5.5 to around 6 is linked to a decrease in meat tenderness (Kadim et al., 2008). Dark-cutting meat occurs when meat fails to lighten and is described by an increase in the $\mathrm{pH}$ value, high expressed juice, sticky texture and a dark colour due to a depletion of muscle glycogen prior to slaughter (Kreikemeier and Unruh, 1993). In Basrah, the average summer temperature of over $43^{\circ} \mathrm{C}$ and a humidity of over $52 \%$ are normal during the hot season, which could have bad effects on the quality of the animal meat. Therefore, the aim of the current study was to investigate the effect of hot and cool seasons ambient temperature and humidity on meat quality characteristics of hot-boned ovine and bovine longissimus thoracis. The study also aimed at investigating the relationship between $\mathrm{pHu}$ and meat quality under different seasonal temperatures.

\section{MATERIALS AND METHODS}

\section{Environmental parameters}

Weather temperature and relative humidity, as summarized in Fig. 1, were recorded at Basrah region by the Iraqi

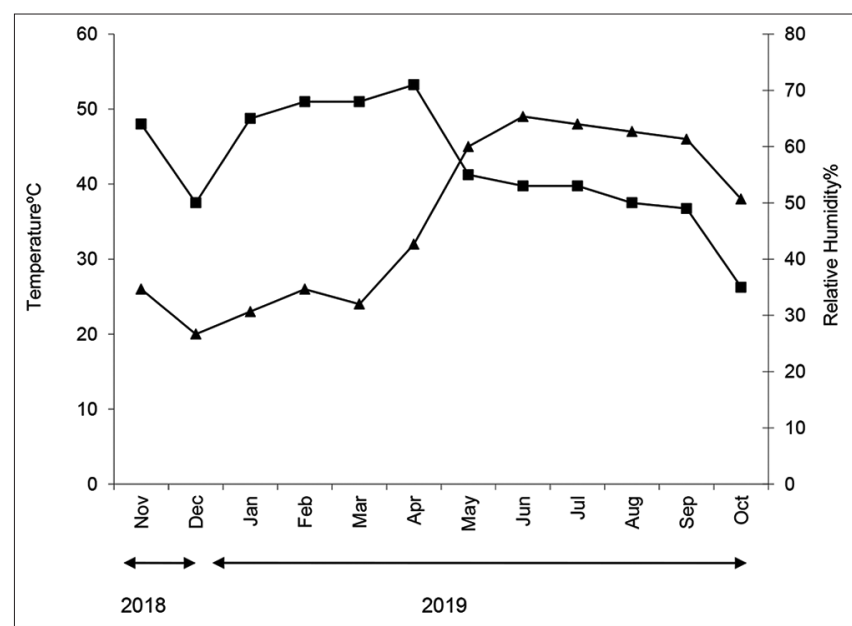

Fig 1. Monthly ambient temperatures ( $\boldsymbol{\Delta})$ and relative humidity (\%) (घ) over the study period (2018/2019).

Meteorological Organization and Seismology. The meat samples collection were done by the Basrah Municipality slaughterhouse. The collection period was between November 2018 and October 2019.

\section{Muscle samples}

Longissimus thoracis samples were randomly collected from 96 Arabi sheep (1-2 years old) and 48 Janubi cattle (1-3 years old) slaughtered at the Basrah Municipality slaughterhouse. Animals were slaughtered after having been held in lairage for $1-2 \mathrm{~h}$ and were dressed following normal commercial slaughterhouse procedures. Longissimus thoracis muscles of each right side, in the region of ribs 8-12 (500 $\mathrm{g}$ from cattle and $200 \mathrm{~g}$ from sheep), were removed within $30 \mathrm{~min}$ postmortem. Samples were placed in label plastic bags and kept in a chiller $\left(4-5^{\circ} \mathrm{C}\right)$ for $48 \mathrm{~h}$ postmortem.

\section{Meat quality}

The procedures of Kadim et al. (2008) were followed for quality petameters such as $\mathrm{pHu}$, expressed juice, cooking loss, shear force, sarcomere length, myofibrillar fragmentation index and color lightness $\left(L^{*}\right)$, redness $\left(a^{*}\right)$ and yellowness (b). For pHu, approximately $2 \mathrm{~g}$ of each muscle sample was homogenized at $20-22^{\circ} \mathrm{C}$ (Ultra Turrax T25 homogenizer, IKA-Werke GmbH and Co. $\mathrm{KG}$ ) then the $\mathrm{pHu}$ was measured using a Metrohm $\mathrm{pH}$ meter (Model No. 744; Metrogm AG CH-9101 Herisau; Switzerland) with a glass electrode. Triplicate of $25 \mathrm{~mm}$ thick slices were cut from each muscle sample were weighed, placed in plastic bags then cooked by immersing in a water bath at $70^{\circ} \mathrm{C}$ for $90 \mathrm{~min}$. The cooking loss $\%$ was determined using the following formula: cooking $\operatorname{loss} \%=(\mathrm{W} 1-\mathrm{W} 2=\mathrm{W} 1) \times 100$. Expressed juice was assessed using a filter paper method, as the total wetted area less the meat area $\left(\mathrm{cm}^{2}\right)$ relative to the weight of 
the sample (g) and calculated according to the following formula: Expressed juice $\left(\mathrm{cm}^{2} / \mathrm{g}\right)=\left(\right.$ Wet area $\left(\mathrm{cm}^{2}\right)$ - meat area $\left(\mathrm{cm}^{2}\right) /$ meat weight $(\mathrm{g})$. For the shear force values, after cooling the cooking samples, 12 cores $(13 \mathrm{~mm} \mathrm{x}$ $13 \mathrm{~mm}$ cross-section) were cut parallel to the orientation of the muscle fibers. Cores were prepared to ensure that shears were made parallel the fibers. Each core was then sheared perpendicularly to the fibers in two places, with Texture Analyzer Machine (Stable Micro Systems, Texture Analyzer, Model TA.XT. Plus, UK). Heliumneon laser with wavelength of $632.8 \mathrm{~nm}$ (Spectra-physics model $1022 \mathrm{~mW}$ laser head) was employed to measure the sarcomere length which was calculated by using a conversion table using an equation described by Bouton et al. (1973). The procedure described by kadim et al. (2004) of laser diffraction was used to determine the sarcomere length. The proportion of muscle fragments that pass through a $231-\mu \mathrm{m}$ screen after the sample had been subjected to a standard homogenization treatment was measured by myofibrillar fragmentation index. A $5 \mathrm{~g}$ $(+0.5 \mathrm{~g})$ sample of diced $\left(6 \mathrm{~mm}^{3}\right.$ pieces $)$ was added to $50 \mathrm{ml}$ of cold physiological saline $(85 \% \mathrm{NaCl})$ plus 5 drops of antifoam A emulsion (Sigma Chemical) in a $50 \mathrm{ml}$ graduated cylinder, and homogenized at $1 / 4$ speed using an $18 \mathrm{~mm}$ diameter shaft on an Ultra-Turrax homogenizer for 30-second periods separated by a 30 second rest period. The homogenate was poured into a pre-weighed filter $(231 \times 231 \mu \mathrm{m}$ holes). The filter typically ceases dripping after 2-3 h, at which time they were dried at 26$28^{\circ} \mathrm{C}$ in an incubator for $40 \mathrm{hrs}$ before being re-weighed. Approximately $60 \mathrm{~min}$ after exposing the fresh surface of the muscle samples, CIE L* (lightness), a* (Redness), and $\mathrm{b}^{*}$ (Yellowness) light reflectance coordinates of the muscle surface were measured at room temperature $\left(20 \pm 2^{\circ} \mathrm{C}\right)$ using a Minolta Chroma Meter CR-300 (Minolta Co., Ltd., Japan), with a colour measuring area $1.1 \mathrm{~cm}$ in diameter. The meter was calibrated using a Minolta calibration plate $\left(L^{*}=97.59, a^{*}=5.00, b^{*}=+6.76\right)$. The $\mathrm{L}^{*}$ value relates to lightness; the $\mathrm{a}^{*}$ value to red-green hue where a positive value relates to the red intensity; and the $b^{*}$ value to the yellow-blue where a positive value is attributed to yellow. The average of two measurements from each sample was recorded as the colour coordinate values of the sample.

\section{Statistical analyses}

The significance of season on meat quality characteristics and the relationship between ultimate $\mathrm{pH}$ and meat quality characteristics in sheep and cattle was evaluated by using the general liner model (GLM) procedures for analysis of variance procedure package Version 9.2 software (SAS 2009). Significant differences between means were assessed using the least-significant-difference procedure.

\section{RESULTS AND DISCUSSION}

\section{Meteorological data}

Fig. 1 presents the daily mean ambient temperature and relative humidity during the collection period. The climate is typically semi-arid with a mean annual temperature of $35.8^{\circ} \mathrm{C}$ and relative humidity of $54.1 \%$. Rainfall is medium and highly inconsistent. The collection period was divided into two seasons. The hot season (April-October) had temperatures between 32.0 and $49.0^{\circ} \mathrm{C}$ and relative humidity $(\mathrm{RH})$ between 35.0 and $71.0 \%$ during day time. The cool season (November-March) had temperatures of $20.0-26.0^{\circ} \mathrm{C}$ with ranges of $\mathrm{RH}$ between 50.0 and $68.0 \%$.

\section{Ultimate $\mathrm{pH}(\mathrm{pHu})$}

Tables 1 and 2 summarized the means and standard errors for meat quality characteristics of the longissimus thoracis muscle for sheep and cattle respectively. The pHu of the muscle varied between 5.65 and 6.91 and between 5.48 and 5.66 (sheep) and between 5.70 and 6.03 and between 5.48 and 5.67 (cattle) for hot and cool seasons, respectively. The mean pHu of sheep muscle sample (5.71) and cattle muscle sample (5.84) for the hot season samples, after 48 hours of postmortem, was significantly $(\mathrm{P}<0.05)$ higher than those from the cool season samples as a result of various levels of heat stress. Hot seasonal temperatures (of over $43^{\circ} \mathrm{C}$ ) and humidity will minimize the heat exchange between the animal body and the environment (Davis and Mader, 2001), causing more physiological stress on animals (Kadim et al., 2004, 2006). In line with present findings, Shi et al. (2016) reported that high ambient temperature affected the meat quality of animals by increasing $\mathrm{pH}$ value probably due to the lower serum concentrations of corticotropin releasing hormone, and inducing a transition of muscle fiber types from IIb to IIx. Ultimate $\mathrm{pH}$ has been reported to be correlated with muscle glycogen level at slaughter (Rosenvold et al., 2001; Węglarz, 2010). It has been reported that low muscle glycogen stores at slaughter do not allow the development of a desirable pHu of the meat after slaughter (Ashmore et al., 1973). However, Apaoblaza et al. (2015) reported that low pHu of cattle longissimus dorsi was not only due to high initial muscle glycogen level, but may be also due to high and sustained activity of adenosine monophosphate kinase and an increased glycogen phosphorlase activity. Therefore, the high pHu of the hot season samples in the present study and in both species is the outcome of a combination of heat stress (average ambient temperature during day time is $43.6^{\circ} \mathrm{C}$ ). The high muscle $\mathrm{pHu}$ as a response to various pre-slaughter stresses including weather temperatures are in in line with previously-published results (Lahucky et al., 1998; Kadim et al., 2004, 2008). Hot weather temperature may have great effect on animal behavior and may impose physiological stress by activating glycogenolysis in animal 
Al-Amri, et al.

Table 1: Means and standard errors for some meat quality characteristics of sheep longissimus thoracis during hot and cool

\begin{tabular}{|c|c|c|c|c|c|}
\hline Measurement & Season & Mean & Standard Error & Minimum & Maximum \\
\hline \multirow[t]{2}{*}{ Ultimate $\mathrm{pH}$} & Hot & 5.71 & 0.069 & 5.65 & 5.91 \\
\hline & Cool & 5.51 & 0.045 & 5.48 & 5.66 \\
\hline Significant ${ }^{1}$ & & * & & & \\
\hline \multirow[t]{2}{*}{ Shear value $\left(\mathrm{kg} / \mathrm{cm}^{2}\right)$} & Hot & 3.59 & 0.345 & 3.12 & 5.67 \\
\hline & Cool & $4 ., 67$ & 0.298 & 3.86 & 6.76 \\
\hline Significant ${ }^{1}$ & & * & & & \\
\hline \multirow[t]{2}{*}{ Sarcomere length $(\mu)$} & Hot & 1.80 & 0.043 & 1.70 & 1.90 \\
\hline & Cool & 1.72 & 0.025 & 1.68 & 1.80 \\
\hline Signifcant ${ }^{1}$ & & * & & & \\
\hline \multirow[t]{2}{*}{ Expressed juice $\left(\mathrm{cm}^{2} / \mathrm{g}\right)$} & Hot & 34.9 & 3.135 & 25.8 & 48.5 \\
\hline & Cool & 35.1 & 2.054 & 30.9 & 47.8 \\
\hline Significant ${ }^{1}$ & & NS & & & \\
\hline \multirow[t]{2}{*}{ Cooking loss $\%$} & Hot & 20.3 & 3.091 & 13.9 & 29.8 \\
\hline & Cool & 21.6 & 1.982 & 16.7 & 29.6 \\
\hline Significant ${ }^{1}$ & & NS & & & \\
\hline \multirow[t]{2}{*}{ Myofibrillar fragmentation index } & Hot & 80.5 & 5.62 & 70.1 & 89.8 \\
\hline & Cool & 75.6 & 4.78 & 66.8 & 85.3 \\
\hline Significant ${ }^{1}$ & & * & & & \\
\hline \multicolumn{6}{|l|}{ Colour } \\
\hline \multirow[t]{2}{*}{ Lightness $\left(L^{*}\right)$} & Hot & 43.6 & 3.15 & 319 & 66.7 \\
\hline & Cool & 47.6 & 2.45 & 38.9 & 61.3 \\
\hline Significant ${ }^{1}$ & & * & & & \\
\hline \multirow[t]{2}{*}{ Redness $\left(a^{*}\right)$} & Hot & 15.9 & 2.25 & 10.7 & 20.9 \\
\hline & Cool & 18.9 & 1.52 & 14.1 & 22.4 \\
\hline Significant ${ }^{1}$ & & * & & & \\
\hline \multirow[t]{2}{*}{ Yellowness $\left(b^{\star}\right)$} & Hot & 8.45 & 0.867 & 5.23 & 10.6 \\
\hline & Cool & 9.99 & 0.784 & 8.79 & 11.8 \\
\hline Significant ${ }^{1}$ & & * & & & \\
\hline
\end{tabular}

${ }^{1}$ Significant: NS; non-significant, ${ }^{*}(\mathrm{P}<0.05)$

muscle (Kadim et al., 2004). Animals under physiological stress use glucose and gluconeogenic precursors as their major oxidative fuels.

Similar to the current results, kadim et al. (2004) and Mounier et al. (2006) concluded that beef obtained during the cold season was characterized by lower $\mathrm{pHu}$ compared to beef collected in the hot season. Moreover, Kadim et al. (2008) proved that physiological stress decreases ruminants' performance when the temperature increased from 20.3 to $29.3^{\circ} \mathrm{C}$. Also, Davis and Mader (2001) reported that physiological stress could occur in animals at temperature only slightly higher than $20^{\circ} \mathrm{C}$. Ultimate $\mathrm{pH}$ can also markedly affect other meat quality parameters, including tenderness, colour, expressed juice, myofibrillar fragmentation index and cooking losses. Therefore, $\mathrm{pHu}$ has been widely used as an indicator of potential meat quality (Jelenkova et al. 2008; Kadim et al., 2004, 2008; Knox et al., 2008; Li et al., 2014). Moreover, the tenderization rate is associated with $\mathrm{pHu}$. At high $\mathrm{pHu}$ value, meat tenderizes more rapidly than at low $\mathrm{pHu}$ value during ageing (Silva et al., 1999). The later authors concluded that the tenderness of beef longissimus thoracis muscle was significantly higher in the DFD muscle group than in the Normal one and a significant linear relationship was found between ultimate $\mathrm{pH}$ and tenderness.

\section{Expressed juice}

The expressed juice (water-holding capacity) and cooking loss $\%$ were not significantly different but numerically lower as a result of the weather temperature. According to Gregory (2010), switching to heat-tolerant Bos indicus cattle could lead to tougher, less juicy meat with lower marbling. The results reported in the present study are for longissimus thoracis muscle samples removed from the carcass pre-rigor in a way that was likely to cause some muscle cold shortening. High $\mathrm{pH}$ meats has a greater waterholding capacity than those of low $\mathrm{pH}$, which increases compactness and light absorption was observed in the hot season samples $(19.8 \%)$ compared to the cool season ones (26.0\%) (Abril et al., 2001).

\section{Shear force value}

Shear force value is known as one of the most important characteristics that determine the consumer eating satisfaction of meat (Jelenkova et al., 2008). Tenderness of animal meat and rate of tenderization depend on 
Al-Amri, et al.

Table 2 : Means and standard errors for some meat quality characteristics of cattle longissimus thoracis during hot and cool

\begin{tabular}{|c|c|c|c|c|c|}
\hline Measurement & Season & Mean & Standard Error & Minimum & Maximum \\
\hline \multirow[t]{2}{*}{ Ultimate $\mathrm{pH}$} & Hot & 5.84 & 0.44 & 5.70 & 6.03 \\
\hline & Cool & 5.56 & 0.35 & 5.48 & 5.67 \\
\hline Significant & & * & & & \\
\hline \multirow{2}{*}{ Shear value $\left(\mathrm{kg} / \mathrm{cm}^{2}\right)$} & Hot & 5.65 & 3.64 & 3.23 & 8.78 \\
\hline & Cool & 9.34 & 1.75 & 7.14 & 14.6 \\
\hline Significant ${ }^{1}$ & & * & & & \\
\hline \multirow[t]{2}{*}{ Sarcomere length $(\mu)$} & Hot & 1.80 & 0.084 & 1.61 & 1.89 \\
\hline & Cool & 1.73 & 0.062 & 1.61 & 1.81 \\
\hline Signifcant ${ }^{1}$ & & * & & & \\
\hline \multirow[t]{2}{*}{ Expressed juice $\left(\mathrm{cm}^{2} / \mathrm{g}\right)$} & Hot & 34.9 & 4.98 & 30.3 & 41.2 \\
\hline & Cool & 35.6 & 2.56 & 31.0 & 39.9 \\
\hline Significant & & NS & & & \\
\hline \multirow{2}{*}{ Cooking loss $\%$} & Hot & 19.8 & 4.47 & 14.3 & 28.2 \\
\hline & Cool & 26.0 & 2.07 & 23.3 & 29.8 \\
\hline Significant & & NS & & & \\
\hline \multirow[t]{2}{*}{ Myofibrillar fragmentation index } & Hot & 77.9 & 6.18 & 66.3 & 88.3 \\
\hline & Cool & 72.6 & 5.76 & 61.8 & 85.9 \\
\hline Significant & & * & & & \\
\hline \multicolumn{6}{|l|}{ Colour } \\
\hline \multirow[t]{2}{*}{ Lightness $\left(L^{*}\right)$} & Hot & 31.5 & 2.88 & 19.6 & 36.4 \\
\hline & Cool & 35.6 & 1.30 & 33.3 & 29.8 \\
\hline Significant & & * & & & \\
\hline \multirow[t]{2}{*}{ Redness $\left(a^{*}\right)$} & Hot & 18.5 & 2.26 & 15.9 & 23.9 \\
\hline & Cool & 23.2 & 0.97 & 21.6 & 25.6 \\
\hline Significant & & * & & & \\
\hline \multirow[t]{2}{*}{ Yellowness $\left(b^{\star}\right)$} & Hot & 4.16 & 0.81 & 3.04 & 5.52 \\
\hline & Cool & 6.40 & 0.44 & 5.25 & 6.90 \\
\hline Significant & & * & & & \\
\hline
\end{tabular}

${ }^{1}$ Significant: NS; non-significant, * $(\mathrm{P}<0.05)$

many intrinsic and extrinsic factors including slaughter conditions. The shear force values of both species in the present study were significantly $(\mathrm{P}<0.01)$ lower in longissimus thoracis muscle samples collected during the hot season than in the cool season. Kadim et al. (2004) reported very close values for cattle and sheep meats. In contrast, Chulayo and Muchenje. (2013) reported higher values for sheep longissimus thoracis shear force in summer season than in winter season. Meat of high $\mathrm{pHu}$ is suggested to be tenderer than normal $\mathrm{pH}$ meat as a result of a higher tenderization rate (Dransfield, 1996). In the current study the removed longissimus thoracis muscles from both species during cool season (cold ambient temperatures) while still in a pre-rigor condition, cold shortening may take place. Therefore, some of the cool seasonal muscles in this study might have undergone cold-shortening in particular at low ambient temperatures of the year, which has been shown to be associated with considerable toughening. The sarcomere length measurements were significantly different in the two season groups, with the longissimus thoracis muscle samples from hot season had significantly $(\mathrm{P}<0.05)$ longer sarcomere than those from cool season group in both species (Tables 1 and 2). Similar results were reported by Kadim et al, (2004, 2008) for sheep and cattle muscle samples. The present results support the cold shortening phenomena, which indicated that partially responsible for the greater increase in shear force values of the cool season samples. Cold-shortening and high shear force values would have been more likely for the cool-season samples because of the lower ambient temperature and because with a higher glycogen content, they would have remained in the pre-rigor state for long time (Kadim et al., 2008).

\section{Myofibrillar fragmentation index}

Myofibrillar fragmentation index can be considered a suitable indicator of the extent of protein degradation of meat postmortem (Olson et al. (1976). The Myofibrillar fragmentation index was significantly $(\mathrm{P}<0.05)$ lower in muscles during the cool season than the hot season muscle samples, which may possibly be due to muscle pHu variation (Tables 1 and 2). In accordance with the current results, Silva et al. (1999) found that the myofibrillar fragmentation index in meat sample was significantly higher at pHu 6.5 than those at 5.7. The differences in proportions of fragmentation of muscle myofibrillar proteins may account for differences in meat tenderization 
(2006; Kadim et al., 2008). High muscle pHu is favorably solubilized titin, filamen, neubulin and myosin heavy chain protein (Claeys et al. (1994). With the exception of myosin, calpain enzyme can degraded most of the muscle proteins (Goll et al., 1983), which has an optimum effect on $\mathrm{pH}$ values near neutrality.

\section{Colour}

The $L^{*}, a^{*}$ and $b^{*}$ values of longissimus thoracis muscles evaluated at $48 \mathrm{~h}$ post-mortem were significantly lower $(\mathrm{P}<0.01)$ in hot season samples than in cool season ones (Tables 1 and 2). Similar relationships between the values of colour parameters $L^{*}, a^{*}$ and $b^{*}$ evaluated in different slaughter seasons were reported by Weglarz (2010). There were higher values for sheep longissimus thoracis $\mathrm{L}^{*}, \mathrm{~b}^{*}$ in summer season than in winter season in sheep (Chulayo and Muchenje, 2013). In contrast, Kim et al. (2003) reported that CIELAB color space $L^{*}, a^{*}, b^{*}$ values were significantly lower in cattle slaughtered in the winter season than those of the spring and autumn seasons. Myoglobin chemical structures and concentration, muscle fiber types, $\mathrm{pH}$, muscle location and function and cooling rate are among the main factors which effect the development of muscle colour (Abril et al., 2001). According to Offer (1991), postmortem protein degradation increases light scattering properties of muscle, which is directly related to $\mathrm{pHu}$ increases $\mathrm{L}^{*}, \mathrm{a}^{*}$ and $\mathrm{b}^{*}$ values. In the current investigation, the low $\mathrm{pH}$ values from the cool season muscle samples might degrade of more protein than high $\mathrm{pH}$ muscle samples to increase the colour values. Kadim et al. $(2004,2008)$ reported that reflectance spectrum values for beef longissimus thoracis muscle was lower at $\mathrm{pHu}$ above 6.0. It has been reported that postmortem glycolysis decreases muscle $\mathrm{pH}$, making it brighter and superficially wet (Swatland, 1989). If the muscle $\mathrm{pH}$ is high, the physical state of the proteins will be above their isoelectric point, therefore, proteins will associate with more water in the muscle and the muscle fibers will be tightly packed (Abril et al., 2001). This phenomena is called Dark, Firm and Dry because no scatter light to the same extent as the more open surface of meat of lower $\mathrm{pH}$ (Kreikemeier and Unruh, 1993). In the present study, animals slaughtered during the hot season had significantly $(\mathrm{P}<0.05)$ higher percentage of muscles classified as Dark, Firm and Dry (pHu greater than 6.0) than did cool season animals. Similarly, Kreikemeier et al. (1998) and Mitloehner et al. (2002) reported that the highest proportion of Dark, Firm and Dry occurred in muscles of animals slaughtered during the hot season. Moreover, Gonzalez-Rivasa et al. (2020) stated that animals subjected to high ambient temperature, have reduced muscle glycogen stores resulting in dark, firm and dry meat with high ultimate $\mathrm{pH}$ and high water-holding capacity. This is might be possibly due to that animals slaughtered during the cool season are less affected by physiological stress and have more glycogen reserve than those slaughtered during hot season. It has been reported that the occurrence of dark-cutting beef can range from 0 to $70 \%$ (Kreikemeier and Unruh, 1993; Mitloehner et al., 2002). In the present study, although the rearing and feeding systems of individual animals used were not known, the main system of finishing animal in Basrah is based on feeding of green grass with concentrate supplementation.

The simple correlation coefficients between certain quality parameters of longissimus thoracis muscles and $\mathrm{pHu}$ in sheep and cattle species for hot and cool seasons are presented in Tables 3 and 4, respectively. The results showed that the correlation coefficients for each season and species were significantly $(\mathrm{P}<0.05)$ different. The range of correlation coefficients from -0.15 to -0.69 (sheep) and from -0.11 to -0.85 (cattle) were found between $\mathrm{pHu}$ and various meat quality parameters. The correlation coefficients between the $\mathrm{pHu}$ and shear force values was significant $(\mathrm{P}<0.05)$ with pooling of all muscle data for each species $(r=-0.46$, and -0.58 for sheep and cattle, respectively). The correlations were differed in magnitude according to the season within each species, $r=-0.69$ (sheep) and -85 (cattle) $(\mathrm{P}<0.001)$ was found for the hot season and $r=-0.22$ (sheep) and -31 (cattle) $(\mathrm{P}>0.05)$ for the cool season. Similar correlated results with lower magnitude were found between the $\mathrm{pHu}$ and sarcomere length, cooking loss and expressed juice for both species (Tables 3 and 4). Kadim et al. (2004) considered that the

\begin{tabular}{|c|c|c|}
\hline & Hot season & Cool season \\
\hline Shear Force value & -0.69 & -0.22 \\
\hline Sarcomere length & -0.35 & -0.21 \\
\hline Expressed juice & -0.30 & -0.15 \\
\hline Cooking loss & -0.45 & -0.18 \\
\hline Myofibrillar Fragmentation Index & -0.65 & -0.31 \\
\hline Lightness $L^{*}$ & -0.49 & -0.40 \\
\hline Redness $a^{*}$ & -0.59 & -0.41 \\
\hline Yellowness $b^{*}$ & -0.37 & -0.29 \\
\hline
\end{tabular}

Table 4 : Simple correlation of cattle meat quality parameters with pHu for hot and cool season samples

\begin{tabular}{lcc}
\hline & Hot season & Cool season \\
\hline Shear Force value & -0.85 & -0.31 \\
Sarcomere length & -0.45 & -0.29 \\
Expressed juice & -0.29 & -0.11 \\
Cooking loss & -0.65 & -0.12 \\
Myofibrillar Fragmentation Index & -0.75 & -0.38 \\
Lightness L* & -0.51 & -0.43 \\
Redness a* & -0.68 & -0.39 \\
Yellowness b* $^{*}$ & -0.46 & -0.27 \\
\hline
\end{tabular}


higher expressed juice of meat of high $\mathrm{pHu}$ contributed to their tenderness. The correlation coefficients between $\mathrm{pHu}$ and myfibrillar fragmentation index indicate that the relationships were negatively significant $(\mathrm{P}<0.05)$ with higher values for hot season than cool season samples. The negative correlation coefficients between muscle $\mathrm{pHu}$ and all colour parameters proved to be significant. The lightness $\left(\mathrm{L}^{*}\right)$, redness $\left(\mathrm{a}^{*}\right)$ and yellowness $\left(\mathrm{b}^{*}\right)$ values for both seasons from sheep and cattle longissimus thoracis muscles were significantly $(\mathrm{P}<0.01)$ related to $\mathrm{pHu}$. Their values ranged from -0.29 to -0.59 for sheep muscle and from -0.27 to -0.68 muscle for cattle, which indicated that high $\mathrm{pHu}$ values caused the deterioration of all colour parameters. Similar conclusions were reported by Weglarz (2010). The range of variation in meat quality parameters during hot season in cattle samples was higher than those in sheep samples. This may be due to that the heavier is the animal, the less ability it has to lose heat due to the relative small surface area compared to its body weight (Babinszky et al., 2011). In general, the overall correlation coefficients between $\mathrm{pHu}$ and certain meat quality parameters were lower in cool-season than hot-season muscle samples, this difference may possibly be due to high variation in the hot-season $\mathrm{pH}$ values.

\section{CONCLUSIONS}

The seasonal ambient temperature and relative humidity had a significant effect on meat quality characteristics of sheep and cattle longissimus thoracis muscles. Animals slaughtered under ambient temperature of approximately $40.5^{\circ} \mathrm{C}$ had higher $\mathrm{pHu}$, myofibrillar fragmentation index and longer sarcomere length, and lower shear force and colour $L^{*}, a^{*}$ and $b^{*}$ values than those slaughtered at $23^{\circ} \mathrm{C}$. This study concluded that the seasonal ambient temperature and humidity in Basrah region were the main reason for differences in quality characteristics of sheep and cattle meats. Physiological stress responses to hot environment can indirectly result in muscle damage, and, therefore, would affect meat quality.

\section{Credit authorship contribution statement}

Isam T. kadim: Conceptualization, Validation, Formal analysis, Investigation, Writing - original draft, Writing - review and editing. Issa Al-Amri: Resources, Writing - review and editing, Dawood S. Al-Ajmi: Writing-review, formal analysis. Abdulaziz Alkindi: Conceptualization, Validation. Alaa A. Sawad: Methodology, Resources. Ahmed Hamaed: Conceptualization, Formal analysis, Resources, Writing - review and editing, Supervision, and Project administration, Amira Nasser: Writing-review, Methodology, Resources.

\section{Declaration of competing interest}

The authors declare no competing interest. There is no animal ethics because the meat samples were randomly corrected from the slaughter house.

\section{ACKNOWLEDGEMENTS}

The assistance of personnel of Basrah Municipality and the Iraqi Meteorological Organization and Seismology who supplied the weather data at Basrah region are acknowledged with appreciation. The competent technical assistance of the University of Nizwa staff are acknowledged.

\section{REFERENCES}

Abril, M., M. M. Campo, A. Onenc, C. Sanudo, P. Alberti and A. I. Negueruela. 2001. Beef colour evolution as a function of ultimate $\mathrm{pH}$. Meat Sci. 58: 69-78.

Apaoblaza, A., A. Galazb, P. Strobelb, A. Ramírez-Revecob, N. Jeréz-Timaurec and C. Gallob. 2015. Glycolytic potential and activity of adenosine monophosphate kinase (AMPK), glycogen phosphorylase (GP) and glycogen debranching enzyme (GDE) in steer carcasses with normal $(<5.8)$ or high $(>5.9) 24 \mathrm{~h} \mathrm{pH}$ determined in M. longissimus dorsi. Meat Sci. 101: 83-89.

Ashmore, C. R., F. D. Carroll, J. Doerr, G. Tompkins, H. Stokes and W. Parker. 1973. Experimental prevention of dark-cutting meat. J. Anim. Sci. 35: 33-36.

Babinszky, L., V. Halas and W. A. Martin. 2011. Impacts of Climate Change on Animal Production and Quality of Animal Food Products, Climate Change-socioeconomic Effects, Juan Blanco and Houshang Kheradmand, IntechOpen, India. Available from: https://www. intechopen.com/books/climate-change-socioeconomic-effects/ impacts-of-climate-change-on-animal-production-and-quality-ofanimal-food-products.

Bouton, P. E., F. D. Carroll, P. V. Harris and W. R. Shorthose. 1973. Influence of $\mathrm{pH}$ and fibre contraction state upon factors affecting the tenderness of bovine muscle. J. Food Sci. 38: 404-407.

Chulayo, A. Y. and V. Muchenje. 2013. The effects of pre-slaughter stress and season on the activity of plasma creatine kinase and mutton quality from different sheep breeds slaughtered at a smallholder abattoir. Asian Aust. J. Anim. Sci. 26: 1762-1772.

Claeys, E., L. Uytterhaegen, D. Demeyer and S. De Smet. 1994. Beef myofibrillar protein salt solubility in relation to tenderness and proteolysis. In: Proceedings of $40^{\text {th }}$ International Congress of Meat Science and Technology (S-IVB. 09), Hague, Netherlands.

Davis, M. S. and T. L. Mader. 2001. Effects of water application to feedlot mounds during the summer. In: Proceedings ASAE $6^{\text {th }}$ International Livestock Environment Symposium University of Minnesota, Minnesota, p. 165-173.

Dransfield, E. 1996. The texture of meat: conditioning and ageing. In: S. A. Taylor, A. R. Raimundo, M. Severini, and F. J. M. Smulders (Eds.), Meat Quality and Meat Packaging. Utrecht, ECCEAMST, Netherlands, p. 65-87.

Goll, E. D., Y. Otsuka and M. Muguruma. 1983. Role of muscle proteinases in maintenance of muscle integrity and mass. J. Food Biochem. 7: 137-177.

Gonzalez-Rivasa, P. A., S. S. Chauhan, M. Ha, N. Fegan, F. R. Dunshea and R. D. Warnera. 2020. Effects of heat stress on animal physiology, metabolism, and meat quality: A review. Meat 
Sci. 162: 108025.

Gregory, N. G. 2010. How climatic changes could affect meat quality. Food Res. Intern. 43: 1866-1873.

Hahn, G. L. and T. L. Mader. 1997. Heat waves in relation to thermoregulation, feeding behavior and mortality of feedlot cattle. In: Proceedings $5^{\text {th }}$ International Symposium Trans Transactions-American Society of Agricultural Engineers, ASABE, Bloomington, MN.

Hashem, M. A., M. M. Hossain, M. S. Rana, M. M. Hossain, M. S. Islam and N. G. Saha. 2013. Effect of heat stress on blood parameter, carcass and meat quality of Black Bengal goat. Bang. J. Anim. Sci. 42: 57-61.

Jelenkova, J., P. Pipek and L. Staruch. 2008. The influence of antemortem treatment on relationship between $\mathrm{pH}$ and tenderness of beef. Meat Sci. 8: 870-874.

Kadim, I. T., O. Mahgoub, D. S. Al-Ajmia, R. S. Al-Maqbalya, S. M. AlMugheiryb and D. Y. Bartolome. 2004. The influence of season on quality characteristics of hot-boned beef $\mathrm{m}$. longissimus thoracis. Meat Sci. 66: 831-836.

Kadim, I. T., O. Mahgoub, A. Y. A. Al-Kindi, W. Al-Marzooqi and N. M. AlSaqri. 2006. Effects of transportation at high ambient temperatures on physiological responses, carcass and meat quality characteristics of three breeds of Omani goats. Meat Sci. 7: 626-634.

Kadim, I. T., O. Mahgoub, W. Al-Marzooqi, D. S. Al-Ajmi, R. S. AlMaqbali and S. M. Al-Lawati. 2008. The influence of seasonal temperatures on meat quality characteristics of hot-boned, $\mathrm{m}$. psoas major and minor, from goats and sheep. Meat Sci. 80: 210-215.

Kim, Y. S., S. K. Yoon, Y. H. Song and S. K. Lee. 2003. Effect of season on color of Hanwoo (Korean native cattle) beef. Meat Sci. 63: 509-513.

Knox, B. L., R. L. van Laack and P. M. Davidson. 2008. Relationships between ultimate $\mathrm{pH}$ and microbial, chemical, and physical characteristics of vacuum-packaged pork loins. J. Food Sci. 73: M104-M110.

Kreikemeier, K. K. and J. A. Unruh. 1993. Carcass traits and the occurrence of dark cutters in pregnant and non-pregnant feedlot heifers. J. Anim. Sci. 71: 1699-1703.

Kreikemeier, K. K., J. A. Unruh and T. P. Eck. 1998. Factors affecting the occurrence of dark-cutting beef and selected carcass traits in finished beef cattle. J. Anim. Sci. 76: 388-395.

Lahucky, R., O. Palanska, J. Mojto, K. Zaujec and J. Huba, 1998. Effect of preslaughter handling on muscle glycogen level and selected meat quality traits in beef. Meat Sci. 50: 389-393.

Lehotayová, A., O. Bučko, J. Petrák, J. Mrázová and O. Debrecéni.
2012. Effect of high ambient temperature on meat quality of pigs. Res. Pig Breed. 6: 37-40.

Li, P., T. Wang, Y. Mao, Y. Zhang, L. Niu, R. Liang, L. Zhu and X. Luo1. 2014. Effect of ultimate $\mathrm{pH}$ on postmortem myofibrillar protein degradation and meat quality characteristics of Chinese yellow crossbreed cattle. Sci. World J. 2014: 1-8.

Mitloehner, F. M., M. L. Galyean and J. J. McGlone. 2002. Shade effect on performance, carcass traits, physiology and behavior of heat-stressed feedlot heifers. J. Anim. Sci. 80: 2043-2050.

Mounier, L., H. Dubroeucq, S. Andanson and I. Veissier. 2006. Variation in meat $\mathrm{pH}$ of beef bulls in relation to conditions of transfer to slaughter and previous history of the animals. J Anim. Sci. 84: 1567-1576.

Nelson, R. N. and D. L. Drazen. 2000. Seasonal changes in stress responses. In: G. Fink (Ed.), Encyclopedia of Stress, Academic Press, United States, p. 402-408.

Offer, G. 1991. Modeling of the formation of pale, soft and exudative meat: Effects of chilling regime and rate and extent of glycolysis. Meat Sci. 30: 157-184.

Olson, D. G., P. C. Parrish and M. H. Stromer. 1976. Myofibril fragmentation and shear resistance of three bovine muscles during postmortem storage. J. Food Sci. 41: 1036.

Rosenvold, K., J. S. Petersen, H. N. Laerke, S. K. Jensen, M. Therkildsen, A. H. Karlsson, H. S. Moller and H. J. Andersen. 2001. Muscle glycogen stores and meat quality as affected by strategic finishing feeding of slaughter pigs. J. Animal Sci. 79: 382-391.

SAS. 2009. SAS User's Guide. Version 9.2. SAS Institute Inc., Cary, NC, USA.

Shi, Z. B., X. Y. Ma, C. T. Zheng, Y. J. Hu, X. F. Yang, K. G. Gao, B. L. Wang and Z. Y. Jiang. 2016. Effects of high ambient temperature on meat quality, serum hormone concentrations, and gene expression in the longissimus dorsi muscle of finishing pigs. Anim. Prod. Sci. 57: 1031-1039.

Silva, J. A., C. Patarata and Martins, C. 1999. Influence of ultimate pH on bovine meat tenderness during ageing. Meat Sci. 52: 453-459.

Swatland, H. J. 1989. A review of meat spectrophotometry (300 to 800 nm). Cana. Instit. Food Sci. Technol. 22: 390-402.

Węglarz, A. 2010. Meat quality defined based on pH and colour depending on cattle category and slaughter season. Czech J. Anim. Sci. 55: 548-556.

Zhang, M., F. R. Dunshea, R. D. Warner, K. DiGiacomo, R. OseiAmponsah and S. S. Chauhan. 2020. Impacts of heat stress on meat quality and strategies for amelioration: A review. Int. J. Biometeorol. 64: 1613-1628. 